\title{
Measuring Human-Induced Land Subsidence from Space
}

Satellite Interferometric Synthetic Aperture Radar (InSAR) is a revolutionary technique that allows scientists to measure and map changes on the Earth's surface as small as a few millimeters. By bouncing radar signals off the ground surface from the same point in space but at different times, the radar satellite can measure the change in distance between the satellite and ground (range change) as the land surface uplifts or subsides. Maps of relative ground-surface change (interferograms) are constructed from the InSAR data to help scientists understand how ground-water pumping, hydrocarbon production, or other human activities cause the land surface to uplift or subside. Interferograms developed by the USGS for study areas in California, Nevada, and Texas are used in this Fact Sheet to demonstrate some of the applications of InSAR to assess human-induced land deformation.

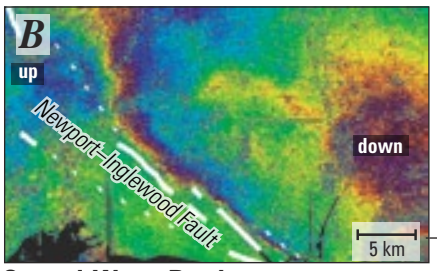

\section{Ground-Water Barriers}

Faults and geologic structures often impede the flow of ground water and can be recognized as linear InSAR features where groundwater levels decline on one side of the fault or rise on the other side of the fault

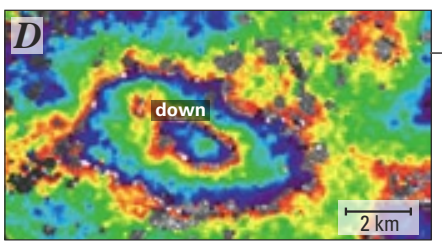

Hydrocarbon Production

The pumping of oil is often imaged as a "bull's-eye" feature, such as the $58 \mathrm{~mm}$ of subsidence measured in the Beverly Hills Oil Field (5 years: Oct. 1993-0ct. 1998)

InSAR provides invaluable spatial information needed to assess and mitigate humaninduced subsidence.

In metropolitan Los Angeles, InSAR imagery found widespread seasonal and annual human-induced surface deformation related to both ground-water and hydrocarbon production. The largest feature in the May-September 1999 interferogram (center) is the 40-km (kilometer) long Santa Ana Basin. Ground-water pumping and artificial recharge are producing as much as $60 \mathrm{~mm}$ (millimeter) of seasonal uplift and subsidence with $20 \mathrm{~mm}$ of net basin subsidence (April 1998-May 1999) (Fig. A). The Newport-Inglewood Fault bounds the southwest margin of the Santa Ana Basin; InSAR shows that there is about a 2-km offset between the mapped trace of the fault and the subsurface ground-water barrier (Fig. B). Many of the
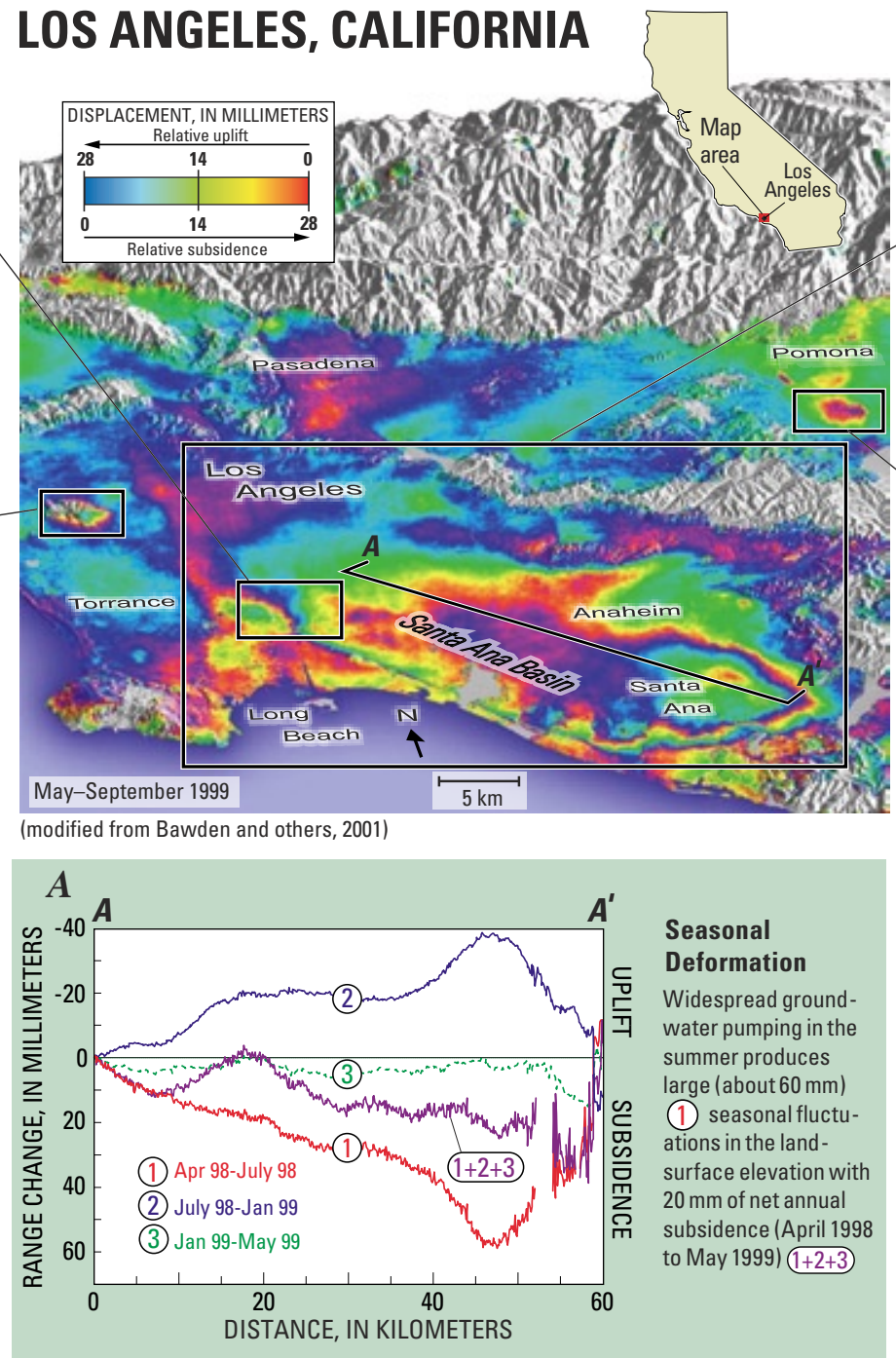

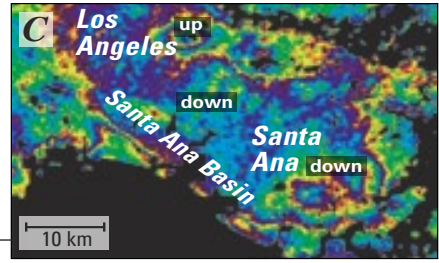

Multi-Year Subsidence As water levels decline near Santa Ana, the land surface subsides at a rate of about $20 \mathrm{~mm}$ per year (Oct. 1993-0ct. 1998)

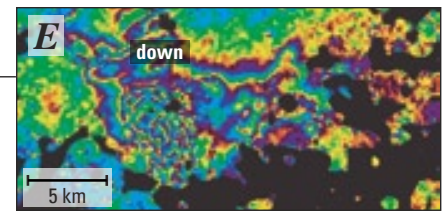

Localized Subsidence

More than $180 \mathrm{~mm}$ of ground-water-pumping induced subsidence (1993-95) resulted in cracked building foundations near Pomona

How to read an interferogram:

1. Count the number of InSAR fringes between two points on the interferogram, where one fringe is one complete color cycle (i.e. yellow, red, blue, green, yellow).

2. Multiply the number of fringes by $28.3 \mathrm{~mm}(1.1 \mathrm{in})$.

3. Determine if the ground moved closer (uplift) or farther away (subsidence) from the satellite by matching how the colors change between the two points with the InSAR scale bar.

(i.e. yellow, red, blue, green shows relative subsidence). deformation features are long lasting (Fig. $\boldsymbol{C}$ ) and can exhibit significant surface deformation as shown by the examples of hydrocarbon production in Beverly Hills (Fig. $\boldsymbol{D}$ ) and property damage near Pomona (Fig. E). Additionally, the human-induced land deformation produces horizontal surface motion that obscures, and in some cases mimics, the tectonic signals expected from the blind thrust faults beneath Los Angeles (Bawden and others, 2001). 


\section{SANTA CLARA VALLEY, CALIFORNIA}

\section{Silicon Valley Subsides}
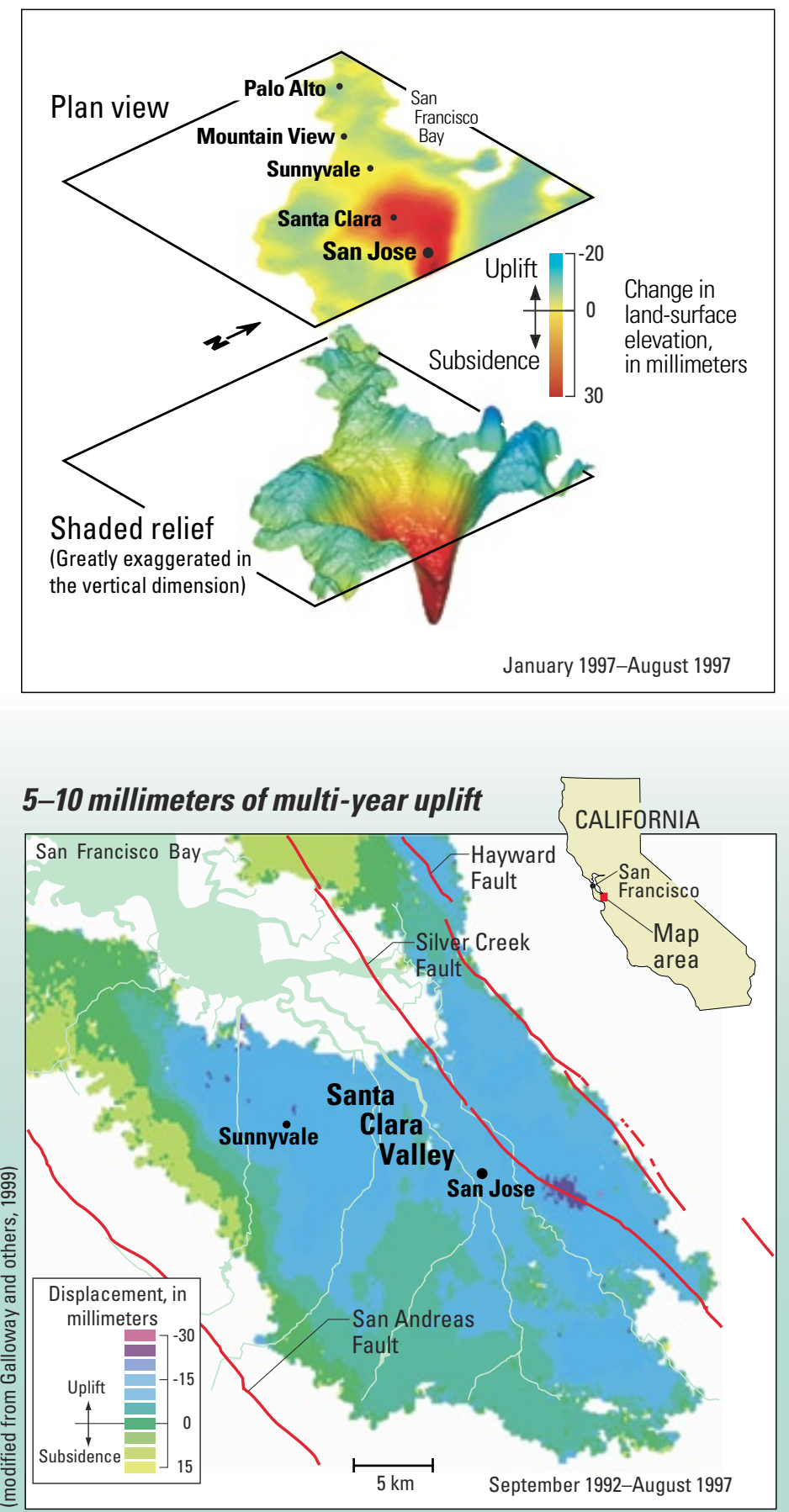

InSAR was used to evaluate seasonal and multi-year deformation patterns, which are critical for implementing appropriate water-management strategies that may include subsidence mitigation. Santa Clara Valley was the first area in the Nation (1940) where land subsidence (nearly $5 \mathrm{~m}$ ) associated with ground-water withdrawal was recognized. A 5-year interferogram (Sept. 1992-Aug. 1997) shows a small amount $(5-10 \mathrm{~mm})$ of regional uplift. The uplift corresponds to a period of water-level recovery throughout the valley. An 8-month interferogram (Jan.-Aug. 1997) shows seasonal subsidence of about $30 \mathrm{~mm}$ near San Jose and corresponds to about a 10-m decline in water levels. The lack of subsidence between 1992-97 indicates that the seasonal subsidence was temporary (Galloway and others, 1999).

InSAR imagery identified new faults and geologic structures in the Santa Clara Valley. The $\boldsymbol{A}-\boldsymbol{A}^{\prime}$ cross section on the 8-month interferogram (bottom-right) shows that the location of the steep subsidence gradient is offset about $1 \mathrm{~km}$ from the mapped trace of the Silver Creek Fault. The USGS Earthquake Hazards Team conducted a seismic reflection/refraction survey across the InSAR feature and identified it as a previously unrecognized fault (Catchings and others, 2000).

\section{0 millimeters of seasonal subsidence}

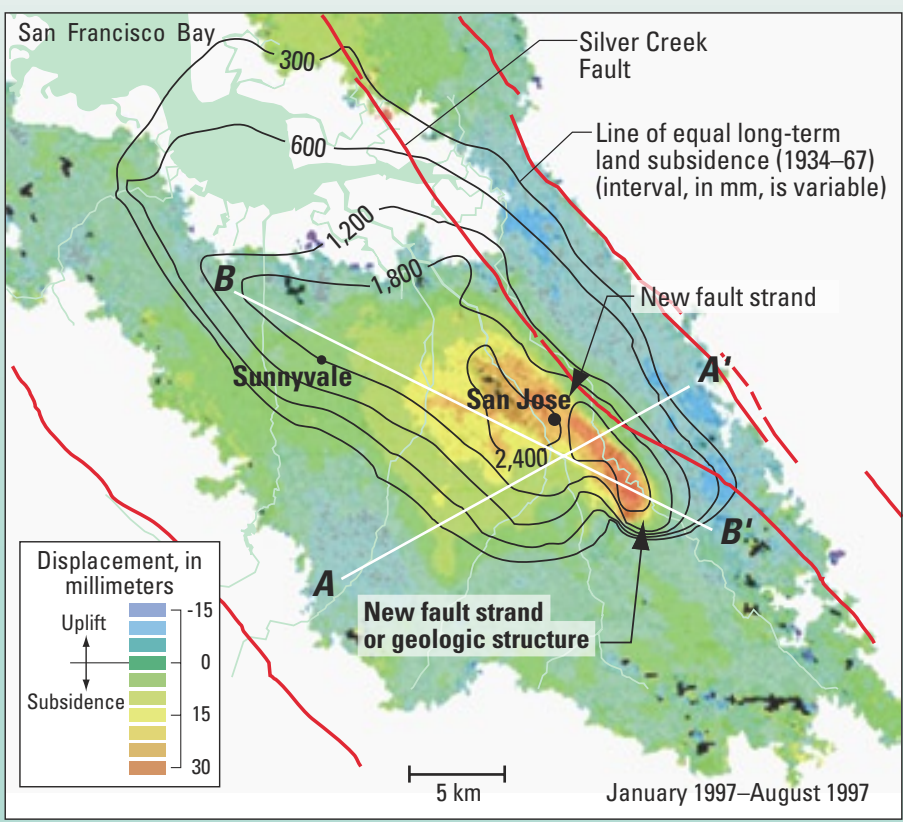

\section{InSAR Finds New Fault Strand}

The $\boldsymbol{B}-\boldsymbol{B}^{\prime}$ cross section (right) shows a steep subsidence gradient in an area where there are no mapped faults, revealing a previously unrecognized structure or fault that also acts as a groundwater flow barrier. Mapping faults and geologic structures in an aquifer system is crucial for understanding ground-water flow, regional subsidence patterns, and potential seismic hazards.

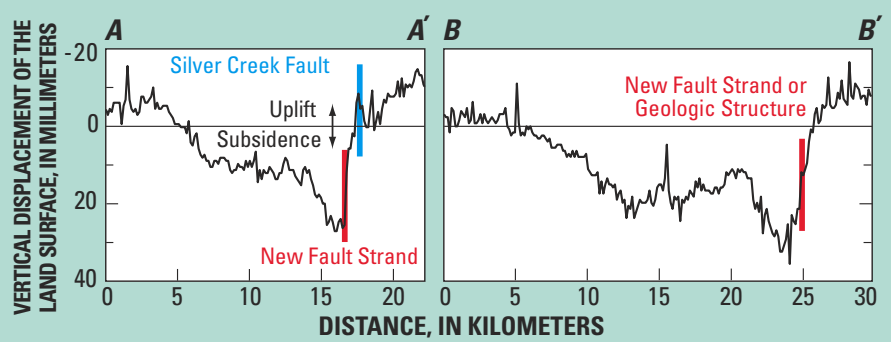




\section{LAS VEGAS VALLEY, NEVADA}

\section{0 millimeters of multi-year subsidence}

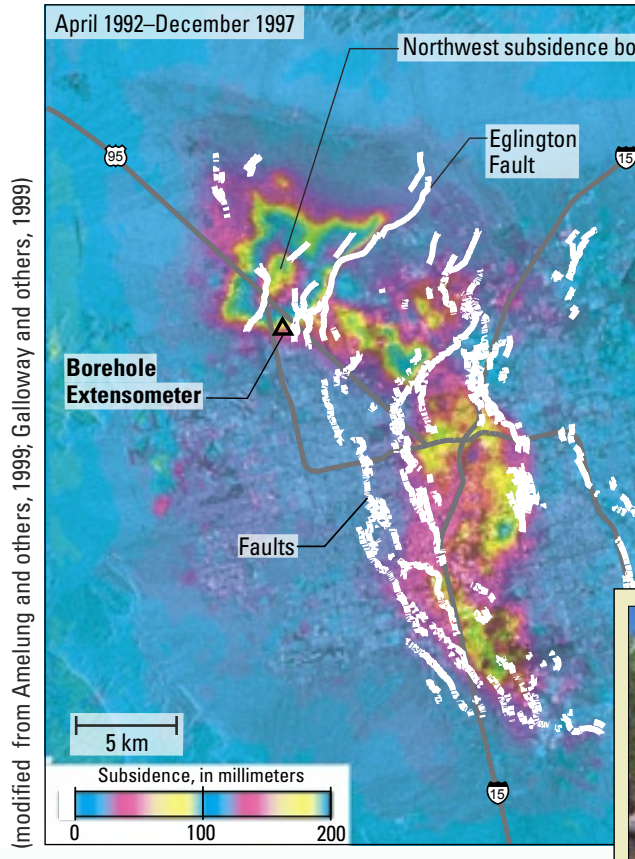

InSAR determined the spatial extent of subsidence and how the subsidence might affect urban development. Las Vegas Valley is one of the fastest growing areas in the Nation. Since the 1950 s, ground-water pumping has resulted in water-level declines of more than $100 \mathrm{~m}$. These large water-level declines have resulted in nearly $2 \mathrm{~m}$ of subsidence, which has caused fissures and damaged wells. A 5-year interferogram (Apr. 1992- Dec. 1997) (left) shows the full extent of the aquifer system and shows $190 \mathrm{~mm}$ of localized subsidence in a distinct bowl in the northwest part of the valley. The southeastern margin of the bowl is structurally controlled by the Eglington Fault.

A borehole extensometer (an instrument to measure aquifersystem compaction) was constructed in 1995 to precisely measure the subsidence. However, interferograms show that the maximum subsidence is located north of the extensometer site. If the InSAR imagery were available prior to extensometer

This well in Las Vegas Valley now extends about 2 meters above the land surface because of subsidence.

Subsidence may also cause well casings in the subsurface to collapse and thereby damaging the well. construction, it may have been constructed in the area of maximum subsidence. While extensometers measure subsidence at only one location, InSAR measures subsidence at thousands of points.

\section{ANTELOPE VALLEY, CALIFORNIA}

\section{InSAR and computer model roughly agree...}

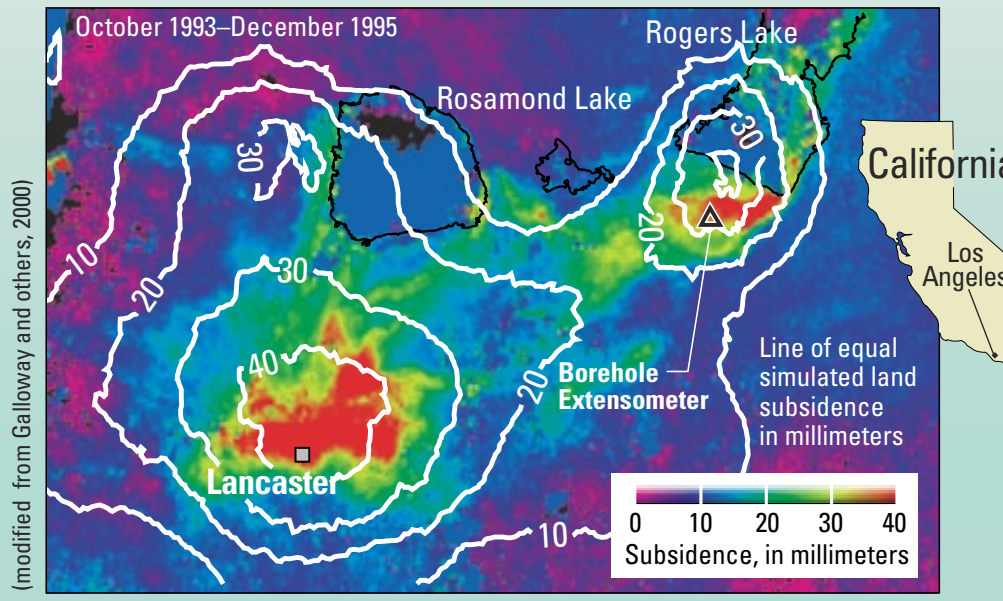

InSAR provides new techniques to calibrate scientific instrumentation and develop sophisticated ground-water models. Extensive pumping in Antelope Valley since the 1940s contributed to nearly $2 \mathrm{~m}$ of subsidence in Lancaster and more than $1 \mathrm{~m}$ south of Rogers Lake, Edwards Air Force Base. During 1993-95, InSAR measured about $40 \mathrm{~mm}$ of subsidence at an extensometer site in the Antelope Valley (upper left); the extensometer measured $31 \mathrm{~mm}$. This disparity indicates that $20 \%$ of the subsidence occurred below the maximum depth of the extensometer $(256 \mathrm{~m})$. InSAR imagery was also used to evaluate a computer model that simulated land subsidence and ground-water flow. A residuals image (upper right) (InSAR observations subtracted from the modeled subsidence) shows

\section{but residuals show added complexities}

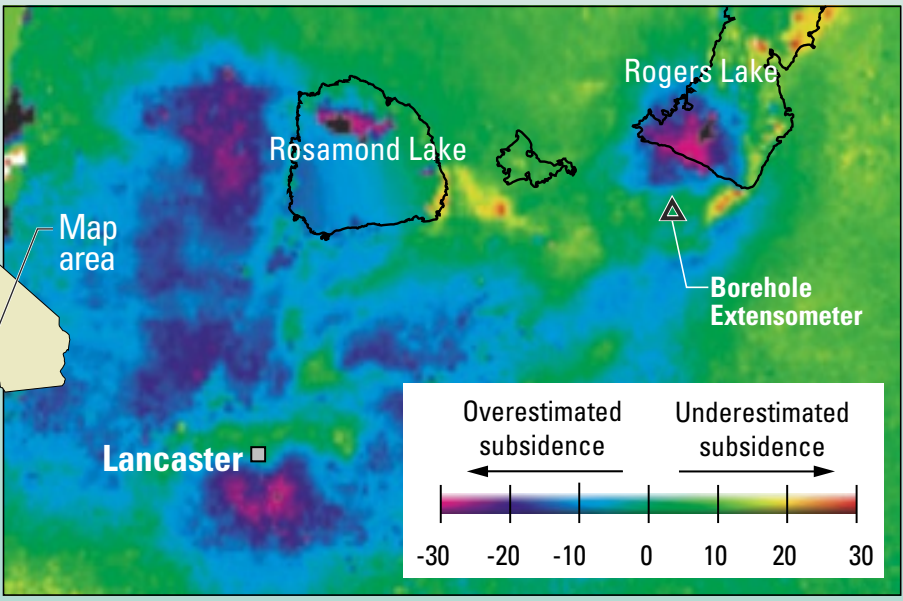

that although the computer model simulated the subsidence reasonably well, it overestimated the subsidence in some areas. These results highlight the potential use of InSAR measurement to better constrain computer models of land subsidence (Galloway and others, 1998; Hoffmann and others, 2003). 


\section{Additional examples of human-induced surface deformation measured with InSAR}

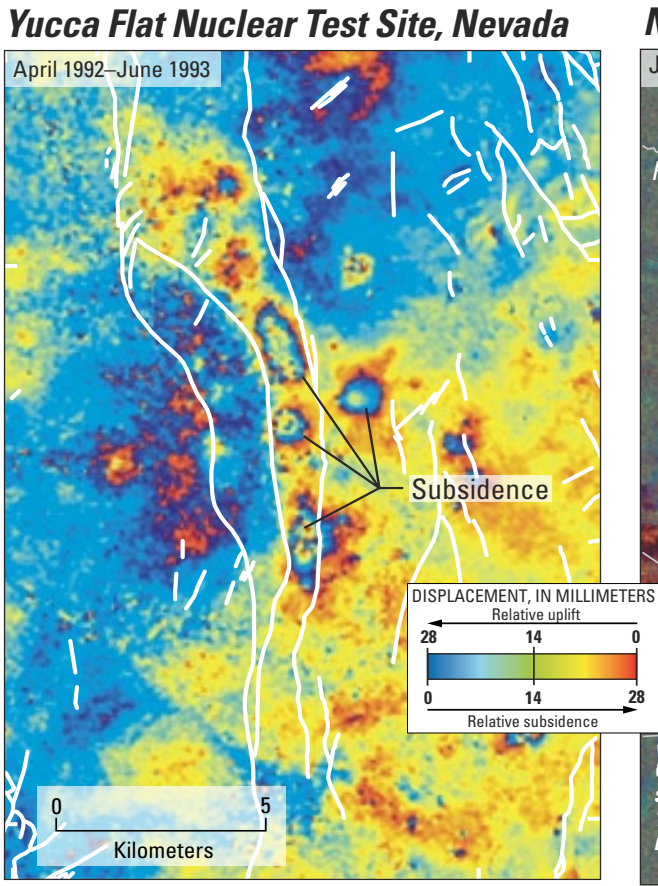

InSAR monitoring shows fault-controlled deformation from the dissipation of residual ground-water pore-fluid pressure changes in response to past underground nuclear weapons testing (R. Laczniak, U.S. Geological Survey, written commun., 2003).

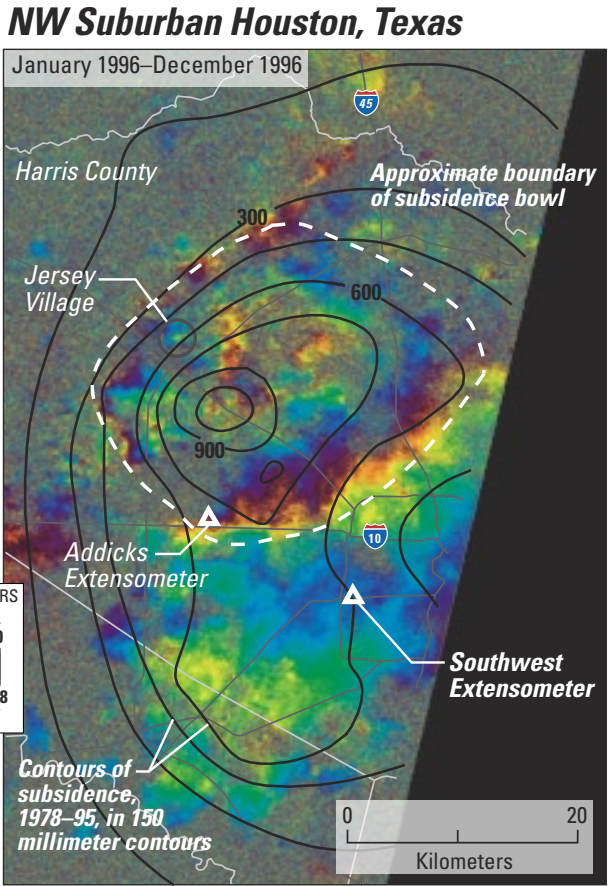

InSAR monitoring shows ground-water subsidence continues to follow historical patterns in the northwest Houston area.

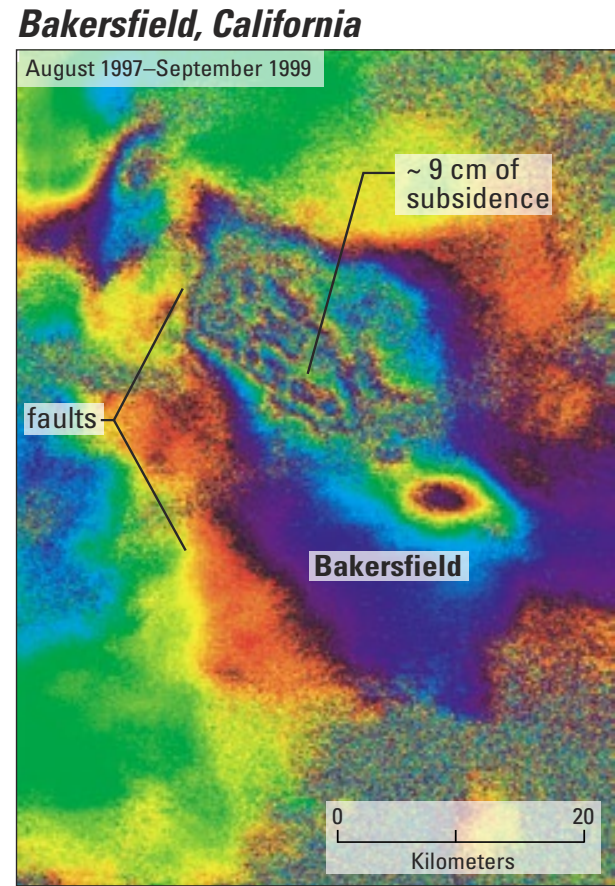

InSAR imagery shows a complex subsidence pattern associated with hydrocarbon extraction north of Bakersfield and shows that faults play a vital role in subsidence.

\section{Advantages of InSAR}

InSAR is ideally suited to measure the spatial extent and magnitude of surface deformation associated with fluid extraction and natural hazards (earthquakes, volcanoes, landslides). It is often less expensive than obtaining sparse point measurements from labor-intensive spirit-leveling and Global Positioning System (GPS) surveys and can provide millions of data points in a region about 10,000 square kilometers. By identifying specific areas of deformation within broader regions of interest, InSAR imagery can also be used to better position specialized instrumentation (such as extensometers, GPS networks, and leveling lines) designed to precisely measure and monitor surface deformation over limited areas.

Radar data used to produce the interferograms shown in this fact sheet were obtained from the European Space Agency, distributed through Eurimage Corporation for the purposes of research and development.

\section{- G.W. Bawden, M. Sneed, S.V. Stork, and D.L. Galloway}

\section{Land subsidence measuring techniques}

\begin{tabular}{|c|c|c|c|c|}
\hline METHOD & $\begin{array}{c}\text { Component } \\
\text { displacement }\end{array}$ & $\begin{array}{l}\text { Resolution }{ }^{1} \\
\text { (millimeters) }\end{array}$ & $\begin{array}{l}\text { Spatial density² } \\
\text { (samples/survey) }\end{array}$ & $\begin{array}{c}\text { Spatial scale } \\
\text { (elements) }\end{array}$ \\
\hline Spirit level & vertical & $0.1-1$ & $10-100$ & line-network \\
\hline Geodimeter & horizontal & 1 & $10-100$ & line-network \\
\hline $\begin{array}{l}\text { Borehole } \\
\text { extensometer }\end{array}$ & vertical & $0.01-0.1$ & $1-3$ & point \\
\hline \multicolumn{5}{|l|}{$\begin{array}{l}\text { Horizontal } \\
\text { extensometer: }\end{array}$} \\
\hline Tape & horizontal & 0.3 & $1-10$ & line-array \\
\hline Invar wire & horizontal & 0.0001 & 1 & line \\
\hline Quartz tube & horizontal & 0.00001 & 1 & line \\
\hline GPS & $\begin{array}{l}\text { vertical } \\
\text { horizontal }\end{array}$ & $\begin{array}{r}20 \\
5\end{array}$ & 10-100 & network \\
\hline InSAR & range & $5-10$ & $\begin{array}{l}100,000- \\
10,000,000\end{array}$ & map pixel ${ }^{3}$ \\
\hline $\begin{array}{l}\text { Measurement resolu } \\
\text { standard geodetic g } \\
2 \text { Number of measurer } \\
\text { dence at the scale o } \\
{ }^{3} \mathrm{~A} \text { pixel on an InSAR }\end{array}$ & $\begin{array}{l}\text { attainable under op } \\
\text { lines. (One inch is eq } \\
\text { ts generally attainab } \\
\text { survey. } \\
\text { lacement map is typ }\end{array}$ & $\begin{array}{l}\text { mum conditions. } \\
\text { al to } 25.4 \text { millimete } \\
\text { under good condit }\end{array}$ & \multicolumn{2}{|c|}{$\begin{array}{l}\text { 2Number of measurements generally attainable under good conditions to define the spatial extent of land subsi- } \\
\text { dence at the scale of the survey. }\end{array}$} \\
\hline
\end{tabular}

\section{References}

Amelung, F., Galloway, D.L., Bell, J.W., Zebker, H.A., and Laczniak, R.J., 1999, Sensing the ups and downs of Las Vegas - InSAR reveals structural control of land subsidence and aquifer-system deformation: Geology, v. 27, p. 483-486.

Bawden, G.W., Thatcher, W., Stein, R.S., Hudnut, K.W., and Peltzer, G., 2001, Tectonic contraction across Los Angeles after removal of groundwater pumping effects: Nature, v. 412, p. 812-815.

Catchings, R.D., Goldman, M.R., Gandhok, G., Rymer, M.J., and Underwood, D.H., 2000, Seismic imaging evidence for faulting across the northwestern projection of the Silver Creek Fault, San Jose, California: U.S. Geological Survey Open File Report 00-0125, $29 \mathrm{p}$.
Galloway, D.L., Hudnut, K.W., Ingebritsen, S.E., Phillips, S.P., Peltzer, G., Rogez, F., and Rosen, P.A., 1998 , Detection of aquifer system compaction and land subsidence using interferometric synthetic aperture radar, Antelope Valley, Mojave Desert, California: Water Resources Research, v. 34, p. 2,573-2,585.

Galloway, D.L., Jones, D.R., and Ingebritsen, S.E., 1999, Land subsidence in the United States: U.S. Geological Survey Circular 1182, 175 p.

Galloway, D.L., Jones, D.R., and Ingebritsen, S.E., 2000, Measuring land subsidence from space: U.S. Geological Survey Fact Sheet 051-00, 4 p

Hoffmann, J., Galloway, D.L., Zebker, H.A., 2003, Inverse modeling of interbed storage parameters using land subsidence observations, Antelope Valley, California: Water Resources Research, v. 39, no. 2, SBH 5.
For additional information on InSAR measured surface deformation, please contact:

Gerald Bawden (gbawden@usgs.gov) U.S. Geological Survey - Placer Hall 6000 J Street

Sacramento, California 95819-6129 916-278-3131

http://quake.wr.usgs.gov/research/ deformation/modeling/socal/la.html http://ca.water.usgs.gov/insar 